University of Warwick institutional repository: http://go.warwick.ac.uk/wrap This paper is made available online in accordance with publisher policies. Please scroll down to view the document itself. Please refer to the repository record for this item and our policy information available from the repository home page for further information.

To see the final version of this paper please visit the publisher's website. Access to the published version may require a subscription.

Author(s): Peter J. Burnell

Article Title: Political Strategies of External Support for Democratization Year of publication: 2005

Link to published version: http;//dx.doi.org/ 10.1111/j.17438594.2005.00016.x

Publisher statement: The definitive version is available at www.blackwell-synergy.com 


\title{
Political Strategies of External Support for Democratization
}

\author{
Peter Burnell \\ Dept. of Politics and International Studies \\ University of Warwick, England
}

\begin{abstract}
Political strategies of external support to democratization are contrasted and critically examined in respect of the United States and European Union. The analysis begins by defining its terms of reference and addresses the question of what it means to have a strategy. The account briefly notes the goals lying behind democratization support and their relationship to the wider foreign policy process, before considering what a successful strategy would look like and how that relates to the selection of candidates. The literature's attempts to identify strategy and its recommendations for better strategies are compared and assessed. Overall the article argues that the question of political strategies of external support for democratization raises several distinct but related issues including the who?, what?, why? and how? On one level strategic choices can be expected to echo the comparative advantage of the 'supporter'. On a different level the strategies cannot be divorced from the larger foreign policy framework. While it is correct to say that any sound strategy for support should be grounded in a theoretical understanding of democratization, the literature on strategies reveals something even more fundamental: divergent views about the nature of politics itself. The recommendations there certainly pinpoint weaknesses in the actual strategies of the US and Europe but they have their own limitations too. In particular, in a world of increasing multi-level governance strategies for supporting democratization should go beyond preoccupation with just an 'outside-in’ approach.
\end{abstract}

\section{INTRODUCTION}

In its World Development Report 2004 the World Bank says international support for promoting democracy has increased tenfold, from 0.5 per cent of official development assistance in 1991 to 5 per cent in 2000, or a grand total of approximately around US\$3 billion annually. Democracy related assistance by the United States is now over $\$ 800$ million annually; European efforts are comparable. The sums look set to increase following President Bush's declared intention to use his second term to promote freedom and democracy abroad; the Europeans will not want to be left behind. So, democratization support is an established and growing industry. Yet in a survey of 40 democracies' efforts to protect and promote democracy abroad only three countries - Canada, Netherlands and Sweden - were rated 'very good' (Democracy Coalition Project, 2002). Thus it seems there is scope to do better.

In reality there is much about the practice of external democracy promotion that we do not know. For although a few writers have described the activities in some detail and ventured to rule on their 
effectiveness (on the United States’ efforts see especially Carothers, 1997 and 1999; on the European Union see for example Crawford, 2000), methodologies for measuring outcomes and impact remain rudimentary. Only now is the United States Agency for International Development (USAID), in conjunction with the US Social Science Research Council endeavouring to devise a credible research design for evaluating its democracy and governance programming: the qualitative data-gathering is projected to take place over 2005 to 2008. USAID is probably well ahead of the rest of the field (but for a pioneering independent assessment of The National Endowment for Democracy's efforts see Scott and Steele, forthcoming 2005). By focussing on strategy this article seeks not to replicate or second-guess the empirical analysis of democracy projects and programmes but instead proceeds from the belief that to explain and improve on the situation described by the Democracy Coalition Project (2002), strategy holds the key.

At its maximum political strategies of external support for democratization cover a large unwieldy canvas. First, democratization itself is a heavily contested and value-laden idea, which means there are competing and wide-ranging alternatives on offer in the literature. Views differ over whether democratization should be defined in purely political terms or instead must refer to equalising social and economic processes too. Major disagreements exist over the adequacy of minimalist accounts that define democratization in terms of the establishment of certain procedures for producing governments such as free and fair elections based on universal suffrage without requiring more substantive political equality or making heavy demands on political participation by society. By comparison there is more agreement that political liberalization means an increase of civil liberties without the introduction of competitive multi-party politics and free and fair elections; liberalization is often a strategy employed by authoritarian regimes to avoid democratic opening. Yet democracies too can be illiberal. And so a particularly useful classification is Diamond's (1996: 21-25) distinction between electoral democracy and liberal democracy. The second makes more extensive provision for political and civic pluralism, and is committed to the rule of law. The former does not offer security to civil liberties and minority rights. Progression towards liberal democracy, which involves attitudinal and behavioural as well as formal organisational changes, is the mainstream understanding of democratization. For the most part that is what the international democracy promotion industry aspires to bring about. So it is that understanding which underlies this article. However, some critics even interpret that commitment as little more than furthering an elitist form of government that prevents a more radical transformation of power relations. For such critics only the full empowerment of the people can effectively challenge the dominance of transnational capital, which for them is democratization truly requires (Robinson 1996). The very normative content of what is being promoted by external support for democratization is, then, contestable. In regard to critical theory it is debatable whether there would be a role for the established liberal democracies to play, or what such a role might be, in supporting alternative democratic models that are untried and untested and seem unlikely to be adopted in the West. Notwithstanding it value, however, the normative debate lies outside the scope of this article, which has the more limited goal of investigating the actualité of international democratization support on the basis of what that support adopts as its objective. 
Democratization could be supported in many different ways, both directly and indirectly - for instance helping society to develop the economic underpinnings that, if not essential to democratic transition may well influence both a democracy’s quality and its long-run survival. Indeed, for some fashionable theories that treat politics as the dependent variable, and more particularly those that regard the development of material forces of production as the principal determinant of political life, the only sensible strategy for supporting democratization would be to address economic issues first. The point can be put rather differently: after society has moved against authoritarianism the best strategy for supporting democratization is to ensure that the people enjoy a 'democracy dividend' - an economic pay-off - to reduce the likelihood of there being a return to the ways of the past. A variant of the economic approach extols the benefits of pursuing economic liberalization first, on the reasoning that economic freedoms and economic markets facilitate the institutionalisation of their political counterparts. However, 'political strategies' can also be interpreted more narrowly, to exclude ways of pursuing democratization via either economic or social development generally or through applying neo-liberal economic solutions to development problems more specifically. Attempts to impose democracy by way of the barrel of a gun are more military than political strategies of support.

The word external in support to democratization conjures up a big field too. It denotes many actors of various types - governments, regional and larger inter-governmental organisations, quasi-independent and non-governmental organisations, commercial and not-for-profit - all seeking to influence the prospects for democracy within countries. The number of such actors based in Europe, the United States and elsewhere has increased considerably over the last 15 years. The Organisation for Security and Co-operation in Europe has been a central actor in the Balkans for instance, and the United Nations (UN) too is increasingly involved (see Newman and Rich, 2005). No single democracy promotion agency operates in a vacuum. Nevertheless if only to make this inquiry more manageable the number of actors and unit of analysis used for illustration here will be the US and the European Union, rather than the multitude of individual democratization support agencies. Unlike the US the EU is not (yet) a state but there has long been a recognition that it conducts external actions, even if until recently it has lacked a comparable, institutionally-grounded foreign policy capability. That said, neither actor should be viewed as monolithic. Indeed, policy choices including those for foreign policy can be understood as the product of complex strategic bargaining among interested parties - actors concerned about their relative power within the institutional matrix, and not necessarily giving priority to policies that will be most rational for the whole (Milner, 1998: 779; 785). For instance Europe’s strategies for democracy support are said to have emerged from 'strikingly inchoate decision-making processes. Rather than...a sophisticated and carefully reasoned conceptual approach, arbitrary accidentalism abounds'. (Youngs, 2004a:13). The situation in the complex bureaucracy of the US federal government may not be vastly different.

Furthermore, just as the state of relations among the external agencies would form a central analytical component of a global political strategy for international support, so we should not compartmentalise 
actors into either external or internal, foreign or domestic. These dichotomies are unhelpful in a world increasingly characterised by outsider-inside relationships and coalitions, where the substance of interactor relations across borders is often what determines outcomes. So although strategy will be discussed here in terms of the approaches of two major actors, a reasonable argument is that greater inter-agency co-ordination (including an appropriate division of responsibilities between official and non-governmental actors) and much closer co-operation between the US and Europe might produce more effective support. Some observers believe such developments would give greater legitimacy to the whole enterprise, especially if the US and EU were to co-operate more closely with the UN and other inter-governmental actors that have regional standing, like the Organisation of American States. Others might see in such 'ganging up' a powerful new imperialism and for that reason be less receptive. And in practice the argument could turn out to be academic. For although the US and Europe do seem to be converging in some aspects of culture, society, economy and, arguably, political ideology, in the post-cold war environment their long-term geopolitical interests could now begin to pull part. In time that may have profound implications for foreign policy generally and co-operation in external support for democratization abroad specifically.

\section{Strategy}

According to Carothers (1997) - described on the cover of his most recent book (2004) as 'the world's leading authority on democracy promotion' - the United States' strategy for democracy assistance has at best been partial, ill thought-out and inadequate. In contrast European democracy promoters are reported to 'lament the lack of overarching "systematic thinking”' that characterises the EU's own efforts (Youngs, 2003: 131). But if the quest for a grand strategy for promoting democratization has so far proved elusive (see Burnell, 2004a) then in politics the meaning of the very term strategy is not easy to pin down. The term may be ubiquitous but there is no substantial conceptual debate, game theoretic literature aside. The literature on democracy promotion is for the most part silent on how strategy differs from 'models', 'policies' and 'approaches' or, indeed, tactics; critiques of the absence of strategy sometimes conflate a 'strategic' approach with a 'more political' approach while concentrating on exploring failings of more technical kind. Traditionally the idea of having strategies and of thinking strategically is more at home in a military context. Indeed the discipline of strategic studies can be defined as inquiries into the ways actors use their military capability to achieve political goals. Increasingly however 'strategy' has been appropriated by business studies - the worlds of product development, marketing, and corporate financial strategy; while in psephology - a sub-discipline of politics - there is the unhelpful remark that 'the terms tactical voting and strategic voting are synonymous' (Oxford Concise Dictionary of Politics, 2003: 531). Different contexts, then, suggest different models. But a minimum consensus would define strategy as an outline of how to achieve goals: the goals are the objective; a strategy sets out the route to that objective, and ideally should estimate the likely cost. Hence thinking strategically is to employ reasoning about means-ends relationships; it offers a framework within which policies and institutional mechanisms can be worked out. Also, strategy should assesses the chances that unwanted side-effects or by-products will put the 
goal further out of reach. That is, it undertakes risk assessment. A strategy should both 'rule in’ provide guidance on what to do - and 'rule out' - guidance on what not to do. Finally, strategy often connotes a game plan for the long term. While it is allowable that 'winning the war' might entail losing some of the battles along the way, it also means being able to recognise when the war has been won (or lost) and knowing when it is time to start thinking about what to do next.

Strategies can range from simple to complex; 'grand strategy' suggests a comprehensive plan but it could still fail to envisage and prepare for every possible eventuality. To think strategically is not necessarily to have a good or optimum strategy, for the simple reason that commentators on these last two may disagree over the best route to take because they read the situation differently or owing to differences in how they conceive the ultimate goal. For instance in the case of consolidated democracy, how many years of stable democracy are needed in order to qualify, which institutional actors must be said to have accepted democratic 'rules of the game', and how widespread must be the conviction that the democratic transition is irreversible?

Although 'wait and see' or 'cautious inaction' might be advisable when approaching certain situations, ‘strategy’ usually implies purposive action. Preparing a defensive strategy can make sense in war or a game of chess, but the idea of being proactive makes most sense in respect of democratization support, so long as it recognises that the principal determinants of success could well be internal to the newly democratizing countries. The relationships between organisation and strategy are variable: the former may dictate the latter, but conversely organisational forms may be devised or reshaped to meet the demands posed by a politically-driven strategic choice. An 'emergent' strategy is one that adapts continuously to circumstances and the environment - particularly appropriate to something like external support for democratization, where our understanding both of the challenge of democratization and of the limits and possibilities of democracy support have evolved considerably over recent years. The old adage that 'everything in strategy is very simple, but nothing in strategy is very easy' also fits well the execution of democratization support, where the political realities on the ground are often uncertain and hard to predict.

\section{WHAT ARE THE GOALS AND WHY?}

A strategy for supporting democratization is not the same thing as the strategy that might lie behind the decision to give support to democratization - the reasons, motives or policy drivers. Ever since the fall of the Berlin Wall there has been confusion - or disagreement - over the primary purpose(s) of political strategies of external support for democratization and their theoretical justification. If democratization is sought largely for its instrumental value then what is the primary objective and how do we understand the relationships between the objects? If liberal democracy is but one of several ends desired by foreign policy, alongside national security, prosperity, global environmental sustainability and so on, is there a rank order or hierarchy? Where are the synergies and what are the trade-offs? While democratization is not synonymous with political liberalization (indeed, either one can take 
place without the other), the nesting of strategies for these two and for human rights as well raises questions about the connections among them. The absence of a clear, workable consensus on the issues among independent analysts runs parallel to the evasions or ambiguities often found in official statements of policy. Big debates in social science over how economic, social and political changes interact - for instance the 'causal' connections among economic growth, social justice, democratization, and political stability, and the implications for a peaceful and prosperous global order - probably never will be fully resolved. The choice of time-scale for assessing the evidence can make a huge difference to the findings. And while some widely-held belief might apply to a 'good' like democracy, as in for example the democratic peace thesis (democracies do not go to war with one another), contrary theorising characterises the process of realising that good (democratization). Up to the point when a liberal democracy finally consolidates in a country the path of political change can actually increase the chances that it will be belligerent, for a variety of reasons (Mansfield and Snyder, 1995; Snyder, 2000). Notwithstanding all the disagreements, a clear sense of the status of any goal such as a world order made up increasingly of democracies - and a reasoned understanding of why that would be desirable, could be considered a sine qua non of a convincing strategy for achieving it.

The distinction between a strategy for supporting democratization and the strategic thinking that lies behind the decision to support democratization brings the nature of the foreign policy process into the foreground. For there is a special institutional sense in which strategies for supporting democratization abroad should begin much closer to home. Indeed for Carothers strategy appears to involve inter alia anchoring democracy support much more firmly in the larger foreign policy process. A place at the top tables would raise the profile of democratization support and might reduce the damage from clashes and contradictions with the other policy goals. In regard to the Middle East for instance that would mean 'taking significant political risks and expending real political capital that up to now has been used in the service of economic and security interests' (2004: 250). In a broadly similar vein The Hague Statement on Enhancing the European Profile in Democracy Assistance (Netherlands Institute for Multiparty Democracy, 2004) says democracy assistance should be a 'core business of EU external policy', not subservient to other foreign policy interests.

These are arguments both for a more ‘joined up’ approach to foreign policy-making in government and for winning the argument for democracy support vis-à-vis other policy objectives among a wider public at home - in the US the Congress and the wider electorate, where a 2004 survey by the Chicago Council on Foreign Relations reported that popular support for promoting democracy had fallen to 14\%, the lowest figure since the survey began in 1974 (Financial Times September 28, 2004). Such findings put the claim that 'We need to democratize foreign policy so that both process and content reflect the values inherent in open democratic societies' (Democracy Coalition Project 2002: 8) in a new light. The need to mobilise public support has also been argued in respect of a strategy of preemptive action to prevent potentially failing states becoming 'rogue' states, by the Commission on Weak States and US National Security (2004). The policy implications of that recommendation may not always coincide with the goal of supporting democratization. However the Commission went on to 
propose a new 'strategy' for spreading democracy too, namely first calculate the likely financial costs of such a policy so as to be able to bid more effectively in the competition for scarce public resources. As an exercise in accountancy that looks highly improbable, given the many unknowns relating to democratization, although as a device to mobilise domestic support it might be politically shrewd. To be really useful, however, a comparable - and even more highly speculative - estimate of the likely costs of not supporting democratization abroad would have to be brought into the equation too.

Moreover even the strategy of seeking a more joined-up approach to foreign policy generally could have ambivalent effects. At the intellectual level it certainly makes good sense for the policy community/practitioners who support democratization and, say officials charged with managing international development co-operation to talk to one another often. The donor community has not systematically allocated development aid to more democratic countries (Svensson, 1999), and so there is a strong case for examining the consequences for democratization of all aid programmes/ projects (including governance capacity-building), rather than concentrating on measuring the effectiveness of democracy assistance alone (Burnell, 2004c). Similar reasoning applies to the democratization effects of big policy initiatives in for example international trade and foreign investment, and to the way all countries are encouraged to adopt neo-liberal economic reforms almost irrespective of the social and political consequences.

In theory all attempts at securing greater policy coherence or complementarity could be asked to observe the principle of 'do no harm' to democratization around the world. Yet the long established practice in the conduct of international affairs is for economic and security rationales to trump concerns for democracy. And that suggests the consequences could be rather different. The policy communities/ practitioner bureaucracies in development, or national security, and those in democracy support are of such unequal size and resources - with the former always under pressure to demonstrate quick results that there are dangers for the latter in getting too close to the former and their concerns. To illustrate, one argument for offering support to increased involvement by national parliaments and political parties in the governmental budget process is to make executives more accountable. That helps build democracy. But a more co-ordinated approach with the development economists could easily turn into an exercise for 'educating' the politicians to accept the harsh realities of fiscal discipline - and stop using parliamentary forums to press high spending demands. A more integrated approach to policy then may lead to fewer not more concessions being made to the objective of democratization.

Something like this seems to have happened already in respect of the Middle East Partnership Initiative (MEPI) - with a budget of $\$ 75$ million - and the 'war on terror', in the US. Accordingly Carothers (2005) now argues MEPI should be moved out of the State Department and reconfigured as a private foundation, if it is to enjoy the kind of autonomy that will be essential to becoming a more effective instrument for democracy promotion. Anyway the broad speculation that democratization will advance such other and distinctive policy goals as national security or global prosperity is not yet fully underwritten by social science. Analysts collectively present different views on the relevant means- 
ends relationships, they vary their hypotheses according to the time frame and, often, venture only cautious and highly qualified interpretations of the data.

In sum, strategy cannot be discussed in isolation from the reasons for promoting democratization and the relative weights that are attached to different policy goals, the linkages between them, as well as issues to do with institutional balance of power.

\section{SUCCESSFUL STRATEGY}

Investing in devising and then implementing a strategy suggests a strong commitment to achieving the objective, a keen desire to be successful. Strategies are more likely to achieve their objectives if they incorporate the lessons of past successes and learn from any failures. But where the objective is democratic progress, what constitutes success? The increase in number of democracies in the world is not itself proof of successful external support. So how do we know if support is successful?

There is a small literature on the difficulties involved in measuring the effects of democracy support and assessing its wider impact on democratic institutionalisation (for example Crawford 2003). Even where individual democracy programmes/ projects can be evaluated by some measurable output, for example the number of new civic associations established by foreign funding, aggregating the results into some verdict for civil society as a whole and then estimating the long term consequences for democratization are both methodologically fraught. Assigning specific causal responsibility could well nigh be impossible given the number of direct and indirect influences, domestic and international that have a bearing on politics and political change. By comparison the question 'what would success look like?' looks more manageable. In practice, however, even the answer to that is far from straightforward.

First, there is the distinction between success in terms of achieving democratic progress and success constructed in terms of the underlying reasons or rationales that motivate the external support. Achievement understood in the one might not deliver what was hoped for in the other. In practice the official statements about the democratic objectives of democratization support often tend to be too vague or imprecise for rigorous assessment, and taken in the round they are not wholly consistent.

Second, there are alternative ways of defining success, and they would produce different results. Outcomes could of course be measured against the actual state of democracy in the supporting countries. But the democracies of western Europe and North America have the benefit of many years of practice; they had the luxury of making incremental improvements over a long time. So this yardstick could be too demanding and the expectations overwhelming. Democratization's external supporters first have to be clear about their objective: is it stable democratic governance, or 'high quality' democracy? But even the 'mature democracies' do not furnish exemplars or ideal standards for the latter. There is real concern there about declining levels of participation and trust in the politicians and 
in the political institutions; political parties almost everywhere are said to be in trouble. And some long-cherished freedoms are being eroded as a consequence of anti-terrorist measures by the state and the encroachment of 'patriotism' blended with the culture of fear.

So an alternative is to define a democratic gold standard - or a framework for measuring the same that no country has attained but which could be used to measure achievement. Who is best placed to formulate this, and should there be one universal model or are different versions appropriate for different societies? These are contested issues. The idea that the societies that are being urged to democratize should themselves participate in determining the criteria for assessing democracy performance - and in deciding what constitutes successful support from abroad - is attractive but not easy to put apply. One response is the democratic audit, or democracy assessment, that Beetham et al. (2002) working for the International Institute for Democracy and Electoral Assistance have devised. It claims to offer an analytical framework that is valid for all societies, and which any society can apply for itself, yet remains sceptical about converting what are essentially qualitative judgments into quantitative scores or ranking countries along a single scale. But their inclusion of certain economic and social rights as defining properties of democracy - on the grounds that they are preconditions for the exercise of political and civil rights, and are outcomes of democracy - is debatable. What does this mean for all democracy's other preconditions and likely outcomes? The inference that a society could be denied democratic possibilities because it is as yet unable to secure certain economic and social rights is an uncomfortable one. The assessment methodology's claims to both universalism and relativism - the democratic principles it enshrines are said to possess global reach but societies are licensed to operationalise them in a flexible fashion ('internally generated benchmarks') - looks ambiguous. Perhaps such issues are bound to arouse controversy. And the diplomatic rhetoric of democratization support is hardly different. For example the G8 Declaration on Partnership for Progress and a Common Future with the Region of the Broader Middle East and North Africa, issued in June 2004, ended up acknowledging 'each society will reach its own conclusions about the pace and scope of change'. Movement towards (and away from) democracy is bound to be multi-faceted, so comparing the different aspects in order to summarise the trend and thereby assess the impact of external support is inherently value-laden. For instance is the emergence of a competitive political party system more significant than the development of a vibrant civil society? Should evidence of success in strengthening parties always count for more than successful support for autonomous civic associations?

In any case democratization is generally thought to be a long drawn out process. It may not be irreversible unless certain stringent conditions are met, such as the US\$6000 average per capita income that Przeworski et al. (1996) suggest is the tipping point. And choosing an appropriate moment(s) to assess whether a strategy of support has been successful is also problematic: it is as much political art as scientific timing. Democratization theorists have customarily distinguished between the breakdown of a non-democratic regime, transition to democracy (usually identified with the holding of the first set of reasonably free and fair elections), and democratic consolidation. But not only are the meaning of 
democratic consolidation and its principal indicators much disputed, but what could look like evidence of successful support early on might have to be re-evaluated later, especially if - as sometimes happens - initial appearances of democratic progress turn out to be deceptive.

Finally the gold standard approach or a universal framework alone cannot tell us whether progress should be measured in terms of where a supported country has reached or, instead how far and how fast it has travelled and the resistance that was met - the obstacles overcome - along the way. What allowance should be made for the baseline before the transition to democracy or support for democratization got under way; what consideration should be given to the degree of difficulty? How can we compare ideas of progress - and compare the chances of achieving progress - for countries some of whom are just starting out on the path of political reform and others that may be further advanced but now show signs of regression or are entering a stationary state? These are all matters of judgment, inherently open to discussion, and analysts and democracy promotion agencies should devote mopre reflection to them. That the obstacles and constraints themselves may differ greatly from one place to another poses further complications. It would be entirely wrong to assume that society is never a problem and that it is only the ignorance or objections of certain narrow and reactionary elites that stand in the way. A more fine-grained analysis is essential not least if a recommended strategy for external support is to concentrate on backing the likely winners (see Candidate Selection, below).

Thus for instance on the scale of prospects for democratization that ranges from strong through fair to weak and impossible to predict, the range of different situations that greets external actors includes the following. In the most promising cases both the government and surrounding political elite and much of society too are broadly sympathetic towards democratization, violent civil conflict is absent and society has the broad capability to operate a democracy. The former Baltic republics of the Soviet Union after the fall of communism are an example. The fair category includes a number of possibilities possessing diverse characteristics. One is where is the regime is determined to resist change but society is both enthusiastic and ready for democracy: the benefit of hindsight says Spain around the time of the fall of Franco is a case in point. Another is where 'project democracy' has firm allies and some significant opponents in the country and where what could prove most challenging for attempts to democratize is the number and behaviour of semi-loyal supporters - the fair-weather friends - whose co-operation is conditional, their enduring support cannot be guaranteed. Georgia and Armenia possibly fit this description as do a number of countries in Africa. The weak category obviously includes countries where the regime is resistant and significant sections of society are unprepared or are ill-equipped to assume the obligations and responsibilities of western-style liberal democracy. Perhaps the people are indifferent, hostile even, to some of its demands. While Cuba and North Korea might look like extreme examples, equally unpromising are situations of regime collapse, state fragility, and violent civil disorder currently or in the recent past, as in Angola, Democratic Republic of the Congo, Liberia, and Somalia. Almost impossible to predict could be where the ruling group, or society, or both are deeply divided internally over the merits and desirability of reform or over the particular form it should take (Iran). The same could be said of brand new states or proto-states especially if their arrival 
follows a period of violent conflict (East Timor; Eritrea) or international military intervention (Kososvo).

To follow through with some implications for external democratization support, then, an entrenched authoritarian regime presiding over a functioning state and growing economy poses a (set of) challenge(s) very different from a failed state in an economy devastated by civil war but enjoying an opportunity to make a 'fresh start'. The case for constructing a credible paradigm that links democracy-building with external support in the distinctive conditions of a 'post'-conflict environment - where both state-(re)building and nation-building could be essential - is especially urgent for countries like Afghanistan and Iraq. By their very nature these circumstances call for an overarching strategy - one that integrates with the more specific strategies for peace-building, state building and the generation of a sense of political community, and which understands the sequencing issues and complex choices or trade-offs that are bound to arise. One view is that in circumstances like Iraq's the most important single task is to promote the rule of law, before insisting on elections (Dahrendorf, 2004). A related argument is that in general priority should be given to state (re)building (Ottaway, 2002 and 2003). But a strategic decision to prioritise state security could lay down a pernicious form of path dependence, in which vested interests in frustrating democratization take a firm hold in the interim. If democracy is to be established later then renewed violent struggle - a 'democratic revolution' - might be required to make it possible. In reality what all this tells us that the categorisation of democratization prospects in terms of strong, fair and so on is crude and simplistic. A more complex disaggregation would identify more specific combinations of circumstances and permit closer identification of the degree of difficulty and prospects for success. This is important for candidate selection.

\section{Candidate Selection}

Determining the profile of a successful strategy for supporting democratization is not straightforward, when similar bodies of evidence can generate contrasting but equally plausible interpretations. Moreover additional complications exist over whether to define such a strategy not purely in terms of goal achievement but in relation to the cost or the resources expended. The resources expended on supporting democratization have an opportunity cost. An effective strategy would be one that delivers most 'bang for the buck'. A strategic approach could mean being highly selective in the choice of candidates - making strategic choices in the sense of prioritising the likely winners. For Carothers (2004: 48) for instance a strategic approach would not squander efforts on unpromising cases like Haiti. However political science's predictive powers should not be exaggerated. It can agree on only the most abstract propositions concerning the conditions for successful democratization, such as some measures of national unity and socio-economic achievement, and even these are not iron laws. Quite apart from sharp disagreements about the relative causal significance of structural versus voluntaristic factors in explaining successful democratic transitions, different views exist on precisely which structural forces are most propitious. For instance Doorenspleet’s (2004) empirical investigation rejects 
the traditional view that high economic growth is more favourable than low growth. She finds exactly the opposite and argues that peripheral rather core status in the world system is positive too. On that basis Haiti appears to be a strong candidate for democracy support.

Of the societies that are starting from a very low democratic base and ones that seem 'stuck in transition' it may not be obvious which ones will make most democratic progress. In any case a strategy of backing winners could end up reinforcing existing tendencies whereby democracy support works best where it is least needed. That implies double jeopardy for the societies that are left behind, which seems morally unacceptable if democracy really is a universal value. Indeed, in respect of allocating conventional development assistance many commentators have long argued that a more needs-based approach is the most defensible and is most likely to maximise popular support back home. Where support to democratization after conflict could help prevent a society from returning to violence, then even if the kind of 'democracy' that emerges is not full liberal democracy the returns on the investment in support will be magnified. And needless to say 'backing winners' does not necessarily explain the reality of contemporary policy such as the US's decision to focus on Iraq. Of course the alternative of a 'scattershot' approach would hardly be more credible. That could easily damage the reputational power of democratization's external supporters once they become associated with democratic break-throughs that then stagnate or go into reverse, and especially if support is withdrawn prematurely. To signal that there is little appetite for a sustained commitment could have negative repercussions for democratization elsewhere. That would be bad strategy,

For more constructive guidance on 'where', we could turn to the so-called 'neighbourhood effect', a proposition that claims the chances of registering democratic progress are greater in countries which have borders with other democracies or democratizing countries. (consistent with findings in Dorenspleet 2004). One possibility, then, is that a strategic decision to concentrate support geographically would offer the greatest benefits. A similar principle could apply to matching up 'partners', for example the suggestion that Poland should be in the vanguard of EU attempts to advance democracy's cause in Ukraine and Belarus. Nevertheless, now that everywhere the easy victories for democratization have already been won, candidate selection for future support is becoming harder. Hence the case for sound strategy is more compelling than ever. This issue is especially pertinent to the European Union, and not merely because its global reach does not match that of the US. Since 1989 the most obvious countries for the EU to concentrate on for geo-strategic reasons have also been countries where the predisposing conditions for democratization - economic attainments; a previous history of democratic experiments; solid experience of political party organisation and so on - were already favourable. That happy coincidence is now drawing to a close. Of course the fact that the postcommunist countries had to grapple with multiple economic as well as political transformations suggests that the challenge even there was anything but easy. But that only goes to show how problematic is the business of predicting - in order to support - winners. 
Looking forward, realists have no difficulty in arguing that democratization support should (continue to) prioritise those countries/regions where there are important security or other national interests that would be advanced by political change. Indeed the US’s ‘Greater Middle East democracy initiative’ delineated that region more in terms of its relevance as a 'security region' for the US than in terms of any shared potential for democratic progress. For the European Union in contrast a (continuing) focus on its 'near abroad' (Balkans, southern Mediterranean, and eastern Europe as far as the Urals) could well be the obvious strategic choice. An alternative option would play on historical relationships. Quite apart from any moral obligation that might be thought to arise (such as from a former colonial tie or a bungled attempt to transfer democracy at independence), a unique empathy or special access might be claimed in regard to some sub-Saharan African countries, so aiding the chances of success. A very different starting point would be for supporters of democratization to trade on the special advantages that derive from their own unique political history. Having constructed a lasting peace following centuries of violence - through building the European Union after the second world war and then overcoming the 'cold war' inside Europe - Europe has strong claims to offer something relevant to democratization in 'post'-conflict situations. The US has its own 'backyard', but a further option is for Europe to identify places where the US's difficulties are Europe's opportunities. Wherever the issue of democratization is confused with overbearing American power and creates a resentment that blights the outlook for democracy, a division of responsibilities would suggest that Europe take the lead. Thus although at the global level a (more) strategic approach to supporting democratization recommends greater co-ordination among the main actors - something that has long been canvassed for international development co-operation - in some settings a successful strategy could still be served best by doing things separately.

\section{DEMOCRATIZATION SUPPORT: THE LITERATURE}

Carothers' idea of a 'democracy template’ (1999: 86) - comprising electoral process, state institutions, and civil society, reflecting an idealised view of US liberal democracy-arranges the typical components of conventional democracy support. First there are goals for each of these three 'sectors', such as free and fair elections, and then individual forms of assistance, for example international election observation. The simplest strategy for support refers to choices among these three sectors and their components. The political situation in a country decides where to allocate most attention; strategy involves making adjustments to reflect local political circumstance as they are interpreted (ideally) by well-informed observers. In practice overall strategy has evolved from an initial emphasis on supporting elections through to a considerable faith in the development of civil society. Even so, that kind of progression has been more reactive than planned and could equally well be said to reflect merely tactical shifts. In any case a systematic approach would insist on close co-ordination of support between the three sectors.

Carothers' own reflections on a more comprehensive strategy inspire not one but several themes, such as giving democratization support greater priority within the foreign policy process and allocating it 
more selectively. But his core recommendation rests on the persuasive idea that strategy must be firmly grounded in an understanding, or theory, of the process of democratization. He advances this as a critique of the attachment to a 'normal' sequence of change and the practice of 'institutional modelling' that the US (and by extension others) have favoured in the past. Past endeavours to transfer formal institutional designs - an endpoint approach that aspires to bridge the gap with reality through transferring knowledge and training - ignores both how democracy originated in the US and Europe (Carothers, 1997: 117) and the processes by which it could emerge elsewhere today. The approach treats symptoms and not causes. In place of such a universal recipe Carothers advises that a typology of different strategies should be developed, as would befit a typology of 'political transitions' that resembled the diversity in the real world. The logic is compelling; and for Carothers (2004: 167-83) it dovetails with his thesis that the old 'transition paradigm' - which specified political opening followed by breakthrough followed by democratic consolidation - is now obsolete. A more complex and variable picture exists today, and contains partial and interrupted cases of democratic advance and democratic retreat, together with frozen or stalled cases of what might be called transition to nowhere. Indeed there is not one process of democratization but instead multiple patterns of greater and lesser degrees of political change: in many places the direction of change remains uncertain or is problematic.

At minimum then a strategy for supporting democratization should distinguish between stubbornly authoritarian cases, partial but ongoing transitions, backsliders, and stable semi-authoritarian regimes, as well as treat 'post-conflict' situations as sui generis (see also Gershman, 2004). Of course the reasons why democratic transitions sometimes falter may differ from case to case and the question of what strategy to adopt is particularly important, not simply because the cases are so numerous. Comparative statistical analysis finds intermediate regimes or semi-democracies, not full-blown autocracies to be the most prone to internal repression (Regan and Henderson, 2002) and most susceptible to violent internal conflict (Hegre et al. 2001; Mousseau, 2001). Yet such regimes seem able to acquire a degree of permanence. So, a strategy for support that only weakens authoritarianism, or promotes democratic opening but disengages at the point where an illiberal democracy becomes entrenched, would be reprehensible. A more far-sighted approach would first estimate the chances of making largely uninterrupted progress towards liberal democracy and the time it would take to get there and estimate the 'collateral damage' to citizens' rights or human security along the way. A riskreduction strategy for dealing with the interim should feature in the policy deliberation.

\section{The 'Carnegie Perspective’}

Washington DC's Carnegie Endowment for International Peace does not normally take institutional positions on public policy issues. But in what might be called an unofficial perspective some of its leading analysts of democratization make an assumption that 'politics involves competing interests, struggles over power, conflicting ideologies, and clashing values’ (Carothers, 1997: 123). With few exceptions 'democratic transformation has always been a conflictual, though not necessarily violent process' (Ottaway, 2004: 15); democratization in authoritarian countries cannot occur 'without real 
politics and without conflict' (Hawthorne, 2004: 19). And when noting the incidence of 'mass politics of a conflictual nature', (Hawthorne (2004: 19) observes such 'politics are often accompanied by extensive unrest and violence...fundamental change is always destabilizing to a certain extent'. A strategic approach to supporting democratization where the rulers are resistant would identify the groups outside the power structure who have both the will and the potential capability to mount a serious challenge to the government's hold on power (Carothers, 1997: 128). This calls for 'interestoriented methods of political assessment'. It demands measures that will 'empower those people and organisations who wish to fight to change the patterns of representation' (Carothers, 2000: 154). Political initiatives that are supported at the societal level really must challenge the 'underlying relations of power'; too often, it seems, civil society support has been merely a harmless form of outdoor relief. The prospects for democratization in the Arab world in particular depend on the growth of popular constituencies who at minimum see democracy as a means to gain power and further their interests - motivations that initially might dwell on the anticipated economic and social benefits (Ottaway, 2004: 6).

In this perspective, then, a strategy for external support would combine a selective targeting of countries with a more focused approach to targeting those groups inside countries who look most likely to make a difference - the real agents of change. It would aim to convert their potential capability into effective action. That means extending support beyond the 'usual suspects': single-issue advocacy groups and service-delivery non-governmental organisations, which may lack roots in society. Nevertheless, the devil will be in the detail: identifying and choosing among groups that have both the will and potential to make an impact, as well as determining what weight to give any pro-reform figures in exile, who might have little standing in their own country. An important question is what political methods, tactics and strategies by such groups should be given more support? Activities that come to mind range from street demonstrations and other forms of mass protest that could well be in breach of the law to outright civil disobedience. Political strikes and 'voting with your feet' might be possible even where elections are denied, such as by refusing to pay taxes, resisting conscription, and seeking sanctuary abroad. But if as a last resort people do begin to court violence - the 'ultimate form of politics' (Miller, 1962: 15) - or if the authorities' response to civil disobedience and peaceful riots is brutal repression, then what should democratization's external supporters do next? After all, 'political violence erupts easily when power shifts are occurring' (Carothers, 1999: 337). The silence over what to do in such circumstances is deafening. But the conundrum should not be underestimated, if Bermeo's (2003) finding from comparative historical analysis still applies today. Bermeo claims that the culprits who are chiefly responsible for overthrowing emerging democracies are not the ordinary people but small elite coalitions, overreacting to popular protest, strikes and occasional violence. It would be unimpressive tactically and ethically indefensible to encourage groups to take up conflict only to leave them exposed to oppression once an authoritarian regime reacts harshly, as happened in Iraq at the end of the 1991 Gulf war. It would be understandable if a reputation for behaving inconsistently like this eroded confidence in external support across a wider set of countries. 
Of course Carothers (1999:105) knows that recognising the importance of comprehending the underlying interests and power relationships in a society does not of itself mean that such influential factors can be easily shaped. Two features of a strategy that seek to address this challenge are time and pressure. First, 'strategy' seems to imply an unwavering commitment - for however long it takes. That includes maintaining support during what Dahrendorf (2004) has called the 'valley of tears'. That is the period following authoritarian breakdown or democratic transition when society’s high expectations might be disappointed and democratic enthusiasm could easily wane. This simple strategic advice says two things: be prepared for a long haul, and attach more weight to sustainable long run developments than to short-term concessions. However, supporting change through to some kind of completion poses a benchmark that will be difficult to define, not least because democratic progress is not irreversible, even could be even harder to measure. Nevertheless, similar recommendations exist in critical accounts of international involvement in post-conflict reconstruction/peace-building that reject the external actors' usual preoccupation with having an exit strategy. The second feature, namely pressure, introduces the interesting possibility that strategy could mean adopting a more muscular approach to leveraging democratic change.

Carothers indicates he would support more 'pressure' and a 'greater level of interventionism' (for example 2004: 263; 2005: 7)) to render support to democratization in the Middle East specifically and in semi-authoritarian states more generally. Although diplomacy as a foreign policy instrument has been called 'one of those infuriatingly vague terms that can have different meanings depending upon user and usage’ (White, 2001: 388), ‘diplomatic pressure' is a 'potentially critical element of a prodemocratic policy’ (Carothers, 2004: 263). In the Middle East a direct approach would ‘use a combination of aid for democracy and diplomatic engagement to push (my emphasis) Arab governments to begin building bridges’ (2004: 246) towards democratization. This goes beyond a polite exchange of views and reasoned argument, that is to say persuasion ('pure diplomacy'). Pressure from without is required if (semi-)authoritarians are to be persuaded that their interests or the interests they represent would not be served by resisting clamours for reform from domestic, externallysupported groups. But what does this means in practice?

As a political concept, pressure is undertheorised. Though seemingly harmless in everyday accounts of pressure/interest group activity, the concepts ‘pressure against' and to be 'put under pressure' evoke an exercise of power, potentially coercive even if propelled by benign intent. At minimum there is the deliberate introduction of a cost to the target: the inconvenience and opportunity cost of the resources put into offering resistance. When pressure is effective, the 'target' is caused to concede, to do something it would not otherwise choose to do; compliance may then bring further political or other costs. Furthermore, the perceptions that are held on the two sides of a relationship or among different targets of similar pressure can differ greatly, especially where the actors have different baseline expectations. Thus what is claimed and, perhaps, genuinely believed by the source of pressure to comprise nothing more than an offer, can be received as something much more threatening, or sinister, than that. 
'Diplomatic pressure', then, is a black box of power relationships - actions as well as words ('quiet diplomacy’) - ranging from inducements (irresistible or otherwise) and incentives ('positive conditionalities') to binding contracts and 'negative conditionalities' (deterrents and punishments) and other devices. In extremis there is diplomatic isolation and a range of other sanctions. In practice diplomatic pressure often employs some combination of these at any one instant or over a period of time, such as an offer with strings together with (implied) threat if the offer is declined. None of the Carnegie writers commends military imposition of democracy - where the historical record is weak (Pei and Kasper, 2003; Gates and Strand, 2004). Although if the issue is about restoring state security in failed states, Ottaway and Mair (2004) say the options range from 'co-opting to controlling or fighting' noncivil power-holders. Everyone also knows that excessive foreign pressure can sometimes be counterproductive, stiffening a regime's determination to oppose reform and giving it an instrument to distract the domestic audience, as in Cuba. But the question how far a strategy of applying pressure for democratic progress can legitimately and usefully travel along the continuum from offers to threats, from very 'soft' to very 'hard' (more coercive) forms of power is usually left ambiguous or unconvincing. Sometimes the issue is coyly rolled into condemnations of 'top-down' approaches to supporting democratization, where the comments refer mainly to elite-brokered institutional reforms that frustrate civil society ('bottom up') initiatives, without elucidating the role of external pressure. The issue is especially cloudy where society is genuinely divided over the merits of moving in a more democratic direction, as in Ukraine’s December 2004 presidential elections. Almost half the voters voted for aligning their country more closely with President Putin's authoritarian-style Russia, and against the progressive democratic alternative.

Simple calls for more pressure, then, simply cannot be squared with the rider offered by Carothers (2004: 248) that the external actor's role remains no more than that of 'advocate and enabler'. It is pressure on the anti-reform elements that enables the pro-reform elements to advance their cause. And as yet there is no interventionists charter spelling out the who, how far and by what means external actors can legitimately lend support to groups 'in conflict', unless responding to a humanitarian emergency, the massive abuse of basic human rights, or as a last resort to preserve collective security. Where it is not these situations but democratization that is the goal, international law at present offers no clear endorsement. The implications for non-profit 'non-governmental' agencies that provide democracy assistance courtesy of public funding could merit especially careful consideration here. But clearly the greatest danger with a more muscular strategy is if the legitimacy of external support generally is thrown into doubt, where practices risk offending established norms of sovereignty or offer a poor international advertisement for liberal democratic notions of the rule of law.

Democratization Support and Perspectives on Politics

To summarise so far, operationalising strategy in a way that draws on the unofficial 'Carnegie perspective' on democratization and democracy support would involve both specifying more closely 
the manifestations of political conflict that are entitled to support and opening up the 'black box' of diplomatic 'pressure'. These grey zones might be defended as being more a matter of tactics than anything more fundamental. More striking, however, is that although the premise that strategy should start with analysing the process of democratization is compelling, an understanding of how that process comes about reflects - must reflect - something even more fundamental: a particular view of politics, the political process.

The 'Carnegie perspective' on democratization sees politics as activity, more specifically conflict between groups in pursuit of their interests. In politics 'principles trump interests only occasionally' (Carothers, 1999:337). This perspective has a long tradition in American political science, for instance in the writings of Truman (1951: 514) for whom the activities of political interest groups in conflict comprise the very essence of politics. Even earlier, Bentley (1908: 222) argued that interest is 'nothing more than the group activity itself', and government is totally a matter of 'pressure'; and similarly for Catlin (1930: 70), 'Politics is a perpetual endeavour to avoid being baulked by one's fellow-men'. These views reflect the way politics has always been conducted in the United States. They shape ideas about the well-springs of democratization, the connection being nowhere more explicit than in Latham's (1952: 209) claim that politics may be properly understood 'as the struggle of groups to write in their favour the rules by which the community is governed'. Conflict, then is not alien to democracy. Indeed it is democracy's purported ability to manage and resolve conflict peacefully that is the origin of the advantage often claimed for it over other types of rule - those that rely on maintaining order by means of oppression, intimidation, or indoctrination.

However, the above represents only one perspective on politics from among several possibilities, all having their own implications for how to understand democratization, and so, inferentially, for devising a strategy of external support. For instance a very different understanding of politics is one that can be called politics as belief, values and consensus. Thus Wolin (1961) portrayed politics as a life of common involvements: politics is synonymous with 'public', 'common', or 'general'. Politics is about order, the common good and other solidaristic values. The political art is integrative; political society is no mere accumulation of self-regarding groupings. Politics, then, becomes an interpersonal process of communication (Roelofs 1968); in short, politics as talk rather than action. What this means for democratization is that political elites and non-elites must come to accept ownership of certain values, principles and norms; they must acquire some specific virtues. The feasibility of democracy rests on these assumptions about the normative potential of human beings, the ability to reach consensus on such matters as respect for others, tolerance, sociability, and common regard for the rule of law. It follows that support to democratic progress should transfer and encourage adoption of the same ('norm cascade'), through strategies of partnership and dialogue that will lead to socialisation or social learning. Such a 'values-based' approach to democratization offers an alternative to the reasoning that stresses conflict as a weapon that groups will use to advance their interests. And it does indeed find an echo in democratization support, in the literature on 'normative power Europe'. 
'Normative power Europe’ (Manners, 2002) - ‘normative power’ being the ability to shape conceptions of the 'normal' in such matters as peace, liberty, democracy; rule of law, human rights and norms like social solidarity and anti-discrimination - has been put forward as the EU's distinctive contribution to strategic support for political change. Manners cited the abolition of the death penalty in many countries as an example of EU normative power. Norms are diffused by contagion (unintended), informational diffusion ('strategic communications'), procedural diffusion (agreements), transference (such as technical assistance), overt diffusion (the EU's presence in organisations or third states), and by a cultural filter (interplay between the construction of knowledge and the creation of social and political identity)(Manners, 2002: 244-5). These are examples of influence, not coercive power. So, 'engagement' rather than conflict and certainly not diplomatic isolation characterises this approach to relations with states. Commentators have noted that European support for democratization does not connect with such 'high-politics instruments of democracy promotion' as strong pressure; and Europe’s policy-makers claim this distinction is a strength (Youngs, 2003: 134). Values and norms, not action (especially not coercion) take centre-stage; indeed, 'the most important factor shaping the international role of the EU is not what it does or what it says, but what it is' (Manners, 2002: 252). This modus operandi should not pose enormous difficulties for non-governmental actors in democracy promotion.

However, even this version of a strategy for supporting democratization only takes us so far. Reaching the broad mass of society can be made difficult by a hostile regime; steps to engage with elements of uncivil society may be politically unacceptable all round. The line between socialisation and peer pressure is a hard one to draw: again, different actors may interpret the same activities differently. And the approach begs the question what to do next if persuasion or social learning fail, if democracy's norms do not take hold. Thus although the theory accords closely with the widely-accepted view that for democratization to be sustainable anywhere it must be grounded in a sympathetic political culture, in reality the EU sometimes falls back on a more familiar blend of instruments. That has meant a certain amount of 'institutional modelling' and forms of diplomatic pressure too, including very occasionally the imposition of aid sanctions. But the most notable example is the robust application of positive conditionalities - or more accurately preconditions - for accession to the EU. This has been called hard conditionality, serving democracy promotion through integration (Dimitrova and Pridham, 2004).

Arguably these ex ante 'agencies of constraint' by the EU are currently being elaxed somewhat in respect of certain prospective accession candidates, chiefly Romania and Turkey. And such conditionalities do constitute an obsolescing bargain. Once EU membership has been secured, the deterrence of serious violations of democratic norms by members must rely on threats of diplomatic sanctions, possibly suspension, even though such measures cannot guarantee democratic advance. Membership of itself should create increasing opportunities for socialisation into democratic mores. That is, 'locking in’ following accession enables a longer-term dynamic to set in: 'normative power' takes over, where conditionality expires. But notwithstanding the view of EU enlargement 
commissioner Olli Rehn that ‘values define Europe, not borders’ (Financial Times January 4, 2005)

only a handful of prospective new members remain. So it is not simply the specific

ex ante conditionalities but the overall strategy whereby conditionality gives way to socialisation

courtesy of accession that is obsolescing. The many countries that have or might expect some form of economic association with the EU or that receive EU development aid tied to certain political conditionalities hardly have the same incentive to comply. The threat of exclusion cannot apply to them any more than does the chance of experiencing post-accession socialisation.

However, even if the idea of 'normative power Europe' and an emphasis on dialogue are shown to be an accurate portrayal of how Europe normally goes about supporting democratization, understanding why this approach has been adopted still takes us back to its instrumental worth. The benefit that values-transfer offers to Europe’s geo-strategic interests such as security and not some pure unselfish commitment to universal objectives of democratization and human rights, still appears central to the explanation (see for example Olsen, 2000 and Youngs, 2004b).

\section{BEYOND ‘OUTDSIDE - IN’: SUPPORTING DEMOCRATIZATION IN AN AGE OF MULTI-}

\section{LEVEL GOVERNANCE}

It is often said that studies of democratization's ‘third wave' initially focused on domestic politics and only later brought positive international influences into the analytical frame. Yet both in the literature and in the practical world of external support too little reference is made still to the way the international context sets limits to the kind and extent of democracy that can be built. The point is not that the thinking embodied in external support programmes moulds the theoretical conceptions of democracy and the democratic designs in the new democracies, that is the influence of outsiders on the domestic politics. That important issue has certainly been aired in respect of US and European institutional formulae and the larger claim that they promote a narrow market form of democracy rather than economic and social democracy, to suit their geo-economic objectives (Smith, 2000). Instead the point being made here is that a comprehensive political strategy of external support would address the kinds of challenges to democratization posed by globalization, in particualr the growth of multi-level governance. The point has particular relevance to the EU's newest members, because of the democratic deficit that lies at the heart of the EU, but is not confined to those countries. The challenge is most problematic for small, weak and economically dependent states in the developing world.

The challenge of going beyond an ‘outside-in’ strategy of democratization support stems from the way a powerful, multi-layered 'global governance complex' is shrinking the space available for national political self-determination. For instance there are reckoned to be over 6,500 regulatory agencies at the international level, plus the 'privatisation' of governance to bodies like the bond rating agencies. None of these organisations are democratically accountable. Through their appropriation of important decision-making powers there is a danger that democracy's credibility will be devalued: political apathy and cynicism are possible consequences, in new democracies. Mkandawire (1999) coined the 
term 'choiceless democracies' to characterise the external constraints on elected governments to formulate their economic policies from within the neo-liberal range, perhaps going against popularly expressed wishes at the ballot box. By overriding the principle of responsiveness to electors, the point of political representation comes into question. Furthermore, the national political space where self-rule still remains an option is being penetrated increasingly by a variety of non-accountable external actors (not just the agencies of democratization support), of which transnational corporations are only the most visible. By establishing a presence there and attracting local allies they can capitalise on their great regional or global financial, economic and political clout to capture disproportionate influence in the domestic policy and decision-making processes. Once again, then, power and influence over their own affairs are being denied to the mass of ordinary people, for whom the formal freedoms newly gained from political liberalisation and democratization can appear to carry little weight.

This means that a comprehensive strategy of external support for democratization would not only reflect on power relations and conflicts within states but must also take account of transboundary and supraterritorial forces that are bearing down on the prospects for meaningful democracy. Historically democracy was devised for an epoch when the nation state was truly sovereign; in many respects the situation facing emerging or prospective new democracies especially in the developing world is significantly different. However, whether these new problems for democracy can be addressed satisfactorily within the confines of a globalizing world system and on the basis of trying to preserve the established order of states is the subject of considerable, on-going debate. On the one side there are ' hyper-globalizers' (see Cerny, 1999) for whom the nation state is just about finished as a credible unit of government. On the other hand there are globalization theorists like McGrew (2005) who suggest the Westphalian ideal of sovereign statehood is not obsolete but simply being transformed, and that opportunities to introduce a new, more democratic form of global politics do exist. 'Cosmopolitan democracy’ seeks to reinvigorate democracy within states by extending democracy to relations between and across states. Needless to say consideration of such radical and speculative ideas goes well beyond this article. Here it is possible only to illustrate some incremental implications for practical democratization support.

First, increasing global governance and its effects highlight the limitations of the 'electoralist fallacy' even more than ever. Efforts to improve elections management aimed at reducing irregularities and boosting voters' confidence in the fairness of the electoral process do not address the major issue: does it really matter who wins? Progress towards freer and fairer elections that still leave government hostage to extraneous interests or beholden to institutions external to the electoral process, hardly advance democracy. Notwithstanding the well-known double turnover test for democratic consolidation, some of the concern currently expressed by democratization's supporters that elections be able to produce alternations in government should be devoted to enhancing the opportunity for elected governments to reflect in action the expressed wishes of the electorate. Strengthening their institutional capabilities to engage in policy dialogue with for instance the international financial 
institutions is necessary for them to give stronger representation to particular national interests and demands.

Second, external investment in constitutional crafting and advising on relations of vertical and horizontal accountability between the executive and domestic agencies of constraint, civil-military relations, and the decentralisation of administrative functions may barely affect the informal power structures located at the nexus of the domestic and international political economy. The moral is that we should not exaggerate the likely gains that accrue to liberal democracy, let alone for popular empowerment of the kind that Robinson (1996) prefers.

Third, hitherto democratization support has devoted much attention to civic associations in new democracies - sponsoring such organisations' capacity-building, funding their activities, and pressing governments to provide favourable legal and political context. The intention has been to strengthen civil society vis-à-vis the state in these countries. Of course a collection of civic associations neither makes a civil society nor guarantees that its relations with government - or society more generally will strengthen democracy. No less important, far too little attention is given to improving civil society's ability to make institutions of global governance more accountable. Support for strengthening regional and global networks could play an important role here. The emergence of global civil society is both a feature of globalization and a response to the way political power is leaking away from governments: its potential for democratization has not yet been fully realised. Indeed some analysts (for example Scholte, 2004: 217) argue that global civil society offers the main hope for increasing democratic accountability in global governance. External support could underwrite greater interorganisational collaboration among civic groups, in various ways. The construction and maintenance of transterritorial linkages should be capable of further the representation of nationally-based civic associations in the larger geographical forums. There they are more able to countervail powerful supranational institutions of economic and political governance. On the one side, national and also subnational associations will have more chance of being heard. On the other, the collective strength provided by cross-border networks can help national and sub-national associations fight their corner at home vis-à-vis their own government and the locally represented external interests including agencies of democratization support. That would offer a plus for democratization at the country level.

Statements like the above do not ignore the democratic weaknesses that permeate the internal structures of many civil society organisations. But they do draw attention to the case for trying to overcome both the 'nationalist, statist and territorialist mindsets' (Scholte, 2004: 230) and the absence of self-critical reflection found among civic associations everywhere. Also they invoke the case for opening up democratic space within the institutions of global governance themselves - something that democratization's external supporters have hitherto been completely oblivious to. And of course they argue also for promoting democratic principles within the regional/global structures of civil society representation. Typically the high profile international civil society movements tend to be dominated by members from the West, where superior wealth and technical expertise mean that it is they who 
typically set the agendas. In a similar vein the modest resources the European Commission has allocated to networking among civic actors, as part of its democracy and human rights initiatives for the southern Mediterranean have disproportionately favoured bids from European organisations. In the long run greater commitment to helping organisations in North Africa could prove more effective.

Political Parties: an Expanding Frontier for Supporting Democratization

Finally, Central and Eastern Europe have seen many recent examples of external encouragement to the political parties (see for example Pridham, 2001). But only now are some of the major democratization support agencies beginning to think about greatly expanding this form of support elsewhere (lengthy involvement by Germany’s party foundations constitutes an exception). Whereas formerly support to civil society had become fashionable (once the full significance of the 'electoralist fallacy' gained wide recognition), so political society, more specifically the parties' central importance to representative democracy is now registering increasing attention (for example Burnell, 2004b). Certainly it pushes democratization support towards becoming more closely involved in sensitive domestic political affairs. But to believe that by neglecting parties and concentrating on civic associations, democratization's international supporters can avoid being political and yet still help bring about democracy, is probably false on two counts. First, for civil society to make a difference it must play a political role. Supporting mainly associations that only confirm the basic contours of the political status quo is not unpolitical, but instead exerts its own political bias. Second, there are limits to what any civil society can achieve, especially for democratic consolidation. So, a strategy for democratization must address the weaknesses that afflict parties. Sustainable democracy requires parties that are fit to exercise power, and it needs parties that are capable of holding government to account. However, 'the international community has rarely had a coherent and comprehensive strategy for party development in a country... donors have selected specific areas of assistance largely on the basis of local openings, available resources, and their own interests’ (Kumar, 2004: 7). So, the obvious question is how to go about it?

Support for parties in any country must not be divorced from an idea of what an appropriate party system would look like. And that in turn relates to an understanding not only of the functions parties and party systems perform for stable democracy, but also the role they can play in processes of democratization, which could be subtly different. Hitherto party support has been conceived at the level of the individual parties, especially around election time. The aim: to help with campaigning; the objective: to replicate parties as we know them in the established democracies. The consequences for democratization have been left to take care of themselves. A more strategic approach would invert the ladder: begin by identifying what society most needs, wants and expects from democratization generally and party politics specifically. Then draw inferences for the party system and parties and identify the conditions that must be fulfilled - the processes of change - that would address the relevant shortcomings. From that analysts will learn what, if anything, external actors can do to help, and how. For example, different approaches to and different programmes of support would be indicated where 
what is sought most by society from party politics is social reconciliation and political integration on the one side, or wider economic policy choices and competent economic governance on the other. A strategy for support would address these sorts of considerations at the systemic level. And whereas it is the connections that the parties have with the state that are most noticeable in many new democracies, so external support could aim at correcting the bias by strengthening parties' links with society. A greater social rootedness of political parties would make a significant contribution to democracybuilding, in the estimation of most writers on the parties' dimension of democratization. But so far much of the debate among external support actors has concentrated too narrowly on the respective merits of bipartisan versus multi/non-partisan models of support. The former excels at rendering support rooted in a particular ideological orientation; the latter could have greater advantages for sharing the values of democracy per se.

Finally, there is scope for external agents to support the development of closer relations between parties across the new and emerging democracies, in parallel to comparable efforts directed at civic associations. This networking too could be interpreted both as a manifestation of globalization and as a device to strengthen parties' ability to cope with and respond to globalization's more anti-democratic tendencies, at home and in institutions of multi-level governance. The European Parliament just such a vehicle, albeit with limitations. At the same time there is perception that external support has concentrated on parties that are willing to subscribe to neo-liberal economic principles instead of encouraging a wider ideological spectrum. Even if that is a myth, dispelling the myth would enhance the legitimacy of party support for democratization.

\section{CONCLUSION}

In politics strategy is a rather elusive term. The idea of political strategies for supporting democratization can have multiple referents: this analysis identifies not one but several propositions in search of a parsimonious concept, a coherent approach. A strategy is more than just a route map; it involves a statement of the objectives and a clear understanding of the reasons why they are desired and the level of commitment that will be forthcoming. It must offer guidance on the who, the what, the when and above all the how of support to democratization, and by implication when not and how not to, as well. Although demands for an (improved) political strategy should not be confused with a geostrategic approach to supporting democracy, a realist perspective is that the former will probably have to accommodate to the latter in any case. That said, the call for a more strategic approach reflects an understandable impatience by critics who see democratization support as being excessively influenced by bureaucratic considerations. At best it has often appeared opportunistic by default; at worst nothing more than a tool for pursuing (shifting and, at times, opposing) national security and economic goals.

At least three distinct approaches emerge from the literature. First, reproduce familiar institutional models and invest in democratic capacity building; second, address the underlying power relations and engage in some way with group struggle for change; third engender support for a special set of norms, 
values and principles associated with democracy. Carothers' argument that a strategy for support should reflect a plausible theory of democratization - which incidentally must also include theorising why there is no democratization in some places, and its failures, the reversals and false starts - is correct but is only a starting point. For theories of political change (and stasis too) are relative: they rest on their own selection of ideas about what politics is. Thus the familiar debates in democracy promotion about direct versus indirect measures, about the significance of economic conditions for stable democracy and 'top down' versus 'bottom up' approaches conceal something more fundamental. What is most significant here is not that different perspectives on politics imply different views on what democracy can do for society - the reasons why it is desirable, democracy's value. Certainly such views differ profoundly, especially when differentiating 'good democracy' from democracy. But, rather the fundamental point is that they tell different political stories about where democratization can come from - the underpinnings, what makes it feasible, and thereby what it requires from the international community. If the difference could be summarised as two questions then one of them would reflect on how to change group power relations such that the interests of the greatest number can prevail. The second would ask how to move actors towards 'owning' liberal democracy's defining values, principles and beliefs.

A rational expectation is that external supporters of democratization will know their weaknesses and play to their strengths. Thus we would expect the US to be more ready to resort to 'hard power' and Europe to specialise in 'soft power' techniques. But it is inevitable that the potential gains for democratization from exerting strong pressure will be weighed against the costs. These might range from infringing World Trade Organisation agreements (where trade sanctions are threatened) to compromising humanitarian instincts, where the lever comprises aid denials as towards Mugabe's Zimbabwe. Meanwhile in Azerbaijan we are told by a former US State Department and Pentagon official the US 'would not want pro-democracy parties to take to the streets as they did in Georgia and Ukraine’ (Wayne Murray cited in Financial Times, February 21, 2005). Thus President Bush's notion of 'expending political capital' in support of freedom while it may sum up anticipated returns of favours does not really capture all the repercussions that could follow across US foreign policy as a whole. Even so, prominent writers like Carothers recommend a bolder, more interventionist approach than has been employed to date, although not military coercion. There is a symmetry between the vocabulary used to understand politics within countries judged to be candidates for democratization and the recommendations currently being offered concerning how democratization's external supporters should conduct themselves. One pairing emphasises conflict, interests and pressure, the other dwells on normative power, partnership and social learning. In both cases the terminology describes the essence of politics and says how foreign policy should support democratization. The contrast might be pushed even further. The former tries to mobilise what could be largely instrumental demands for political reform inside countries, and pursues democratization abroad as a means to other foreign policy goals. In the latter, the foreign policy claims to value democracy and human rights for their own sakes and seeks to encourage wholesale conversion to these values in prospective new democracies. In reality of course both models are ideal types and the comparison is overdrawn. 
In practice, then, Europe employs forms of pressure too; and politicians who come to espouse democratic values largely in order to qualify their states for EU membership can envisage no obvious disadvantage in doing so. The EU remains vulnerable to criticisms similar to those levelled against the US: both have employed ‘institutional modelling' and neither has a wholly convincing strategy for supporting democratization outside of the easier cases. As politics is the art of the possible, a realistic strategy would recognise the limits of what external support can achieve. Even when armed with a cogent theory of democratization it should harbour no illusions about where it is unable to make a constructive difference, about those parts of politics it cannot reach; ultimately, strategy would know when to stop.

A sound approach to strategy would begin by attempting to secure the home base and then learning from the past. That means having built-in institutional response mechanisms and a corresponding organisational and political flexibility. The really obvious historical lesson is that the strikingly successful examples of democratization and its support - Germany and Japan after 1945; CentralEastern European countries after 1989 - probably have very limited application elsewhere. Perhaps the safest answer to the question of strategy then is to say that various approaches have some merit: democratization supporters should not confine themselves to selecting just one. At the same time they should be alert to the limits to candidate countries' absorptive capacity for diverse support. Strategies attuned to interest-based actors in conflict and strategies that put values-based commitments to the fore may compete in respect of which one offers the more mainstream perspective on politics - politics as talk versus politics as action. But they need not be entirely mutually exclusive in practice: politics is both talk and action. Strategies should be fashioned accordingly. The practical challenge then could lie in combining conflict and co-operation, in situations where imperfect information and political uncertainties regarding both the regime and societal actors on the ground can make forecasting the consequences problematic. Put differently, strategic thinking should dwell on how to help domestic reformers ('norm entrepreneurs') convert international (democratic) norms into powerful assets enjoying ascending influence in their struggle for political change.

Solutions, however, are likely to raise troublesome questions about the legitimacy of external intervention, and the rights and responsibilities of external actors. These are not yet addressed adequately or in a fully transparent manner in the democratization literature or in global public debate. Yet legitimacy, or the superior worth of liberal democracy/democratization/democrats by conviction over more instrumental rationalisations for these could be one of the most important keys to a truly successful foreign policy strategy for supporting democratization. Perhaps, then, a really visionary strategy would give priority to reconsidering the international legal framework for supporting democratization, address all the relevant normative issues, and proceed to place issues of strategy on a much firmer and transparent normative and legal base. 


\section{ACKNOWLEDGMENT}

An earlier version of this article was presented as a paper at the conference 'Thirty Years of the Third Wave of Democratization: Paradigms, Lessons, and Perspectives', organised by the Wissenchaftszentrum Berlin für Sozialforschung and the German Political Science Association Research Group 'System Change', in Berlin on 10 December 2004.

\section{REFERENCES}

Beetham, David, Sarah Bracking, Iain Kearton, and Stuart Weir (2002) International IDEA Handbook on Democracy Assessment. The Hague: Kluwer Law International.

Bentley, Arthur (1908) The Process of Government. A Study of Social Pressures. Chicago, Ill: University of Chicago Press.

Bermeo, Nancy (2003) Ordinary People in Extraordinary Times. The Citizenry and the Breakdown of Democracy. Princeton, NJ: Princeton University Press.

Burnell, Peter (2004a) Democracy Promotion: the Elusive Quest for Grand Strategies. Intenationale Politik und Gesellschaft 3: 100-116.

Burnell, Peter (2004b) Building Better Democracies. Why political parties matter. London:

Westminster Foundation for Democracy.

Burnell, Peter (2004c) The Domestic Political Impact of Foreign Aid: Recalibrating the Research Agenda. European Journal of Development Research 16: 396-416.

Carothers, Thomas (1997) Democracy Assistance: the Question of Strategy. Democratization 4: 10932.

Carothers, Thomas (1999) Aiding Democracy Abroad. The Learning Curve. Washington, DC: CEIP. Carothers, Thomas (2004) Critical Mission. Essays on Democracy Promotion. Washington, DC: CEIP Carothers, Thomas (2005) A Better Way to Support Middle East Reform. Policy Brief No. 33. Washington, DC: CEIP.

Catlin, George (1930) A Study of the Principles of Politics. London: Gorge Allen and Unwin. Cerny, Philip (1999) Globalization and the Erosion of Democracy. European Journal of Political Research 36:1-26.

Commission on Weak States and US National Security (2004) On the Brink: Weak States and US National Security. Washington, DC: US Centre for Global Development.

Crawford, Gordon (2000), “European Union Development Co-operation and the Promotion of Democracy”. In Democracy Assistance. International Co-operation for Democratizatio,n edited by Peter Burnell, pp. 90-127. London: Frank Cass.

Crawford, Gordon (2003) Promoting Democracy from Without - Learning from Within (Part I). Democratization 10: 77-98.

Dahrendorf, Ralf (2004) “Key note address”. at conference on 'Enhancing the European Profile in Democracy Assistance', organised by the Netherlands Institute for Multi-party Democracy, The Hague, 4-6 July. 
Democracy Coalition Project (2002) Defending Democracy - A Global Survey of Foreign Policy

Trends 1992-2002. http://www.demcoalition.org/html/globa_survey.html >2004, October 16.

Diamond, Larry (1996) Is the Third Wave Over? Journal of Democracy 7: 20-37.

Dimitrova, Antoaneta and Geoffrey Pridham (2004) International Actors and Democracy Promotion in Central and Eastern Europe: the Integration Model and its Limits. Democratization 11: 91112.

Dorenspleet, Renske (2004) The Structural Context of Recent Transitions to Democracy. European Journal of Political Research 43: 309-335.

Gates, Scott and Håvard Strand (2004) “Military Intervention, Democratization, and Post-conflict Stability”. paper presented at UNU-WIDER conference ‘Making Peace Work', Helsinki, 4-5 June.

Gershman, Carl (2004) Democracy Promotion: the Relationship of Political Parties and Civil Society. Democratization 11: 27-35.

Hawthorne, Amy (2004) Middle Eastern Democracy. Is Civil Society the Answer? Carnegie Paper No. 44 (March). Washington, DC: CEIP.

Hegre, Hårvard, Tanja Ellingsen, Scott Gates and Nils Petter Gleditsch (2001) Toward a Democratic Civil Peace? Democracy, Political Change and Civil War, 1816-1992. American Political Science Review 95: 33-48.

Kumar, Krishna (2004) International Political Party Assistance. An Overview and Analysis. Working Paper 33. Clingendael: Netherlands Institute of International Relations.

Latham, Earl (1952) The Group Basis of Politics. Ithaca, NY: Cornell University Press.

Manners, Ian (2002) Normative Power Europe: a Contradiction in Terms? Journal of Common Market Studies 40: 235-58.

Mansfield, Edward and Jack Snyder (1995) Democratization and the Danger of War. International Security 20: 5-38.

McGrew, Anthony (2005) “Globalization and Global Politics”. In The Globalization of World Politics, edited by John Baylies and Steve Smith, third edition, pp. 19-40. Oxford: Oxford University Press.

Miller, John D. B. (1965) The Nature of Politics. Harmondsworth: Pelican Books.

Milner, Helen V. (1998) Rationalizing Politics: the Emerging Synthesis of International, American, and Comparative Politics. International Organization 54: 759-86.

Mkandawire, Thandika (1999) “Crisis Management and the Making of 'Choiceless Democracies””. In State, Conflict and Democracy in Africa, edited by Richard Joseph, pp. 119-36. Boulder, CO: Lynne Rienner.

Mousseau, Demet Y. (2001) Democratizing with Ethnic Divisions: a Source of Conflict. Journal of Peace Research 38: 547-67.

Netherlands Institute for Multiparty Democracy (2004) The Hague Statement on Enhancing the European Profile in Democracy Assistance. The Hague: IMD.

Newman, Edward and Roland Rich (2005) The UN Role in Promoting Democracy. Between Ideals and Reality. Tokyo and New York: United Nations University Press. 
Olsen, Gorm R. (2000) Promotion of Democracy as a Foreign Policy Instrument of ‘Europe’: Limits to International Idealism. Democratization 7: 142-67.

Ottaway, Marina (2002) Rebuilding State Institutions in Collapsed States. Development and Change, 33: $1001-1023$.

Ottaway, Marina (2003) Promoting Democracy after Conflict: the Difficult Choices. International Studies Perspectives 4: 314-22.

Ottaway, Marina (2004) Democracy and Constituencies in the Arab World. Carnegie Paper No. 48 (July). Washington, DC: CEIP.

Ottaway, Marina and Stefan Mair (2004) States at Risk and Failed States. Policy Outlook (September). Washington, DC: CEIP.

Oxford Concise Dictionary of Politics (2003). Oxford: Oxford University Press.

Pei, Minxin. and M. Kasper (2003) Lessons from the Past: the American Record in Nation-building, Policy Brief No. 24. Washington, DC: CEIP.

Pridham, Geoffrey (2001) "Patterns of Europeanization and Transnational Party Co-operation: Party Development in Central and Eastern Europe”. In Party Development and Democratic Change in Post-communist Europe, edited by Paul Lewis, pp.179-88. London: Frank Cass.

Przeworski, Adam, Michael Alvarez, José A. Cheibub, and Fernando Limongi (1996) What Makes Democracies Endure? Journal of Democracy 7: 39-55.

Regan, Patrick .M. and Errol A. Henderson (2002) Democracy, Threats and Political Repression in Developing Countries: are Democracies Internally Less Violent. Third World Quarterly 23: 119-36.

Robinson, William (1996) Polyarchy: Globalization, US Intervention, and Hegemony. Cambridge: Cambridge University Press.

Roelofs, Mark (1968) The Language of Modern Politics. Homewood, Ill.: Dorsey Press.

Scott, James M. and Carie A. Steele (forthcoming 2005) Assisting Democrats or Resisting Dictators? The Nature and Impact of Democracy Support by the United States' National Endowment for Democracy, 1990-1999. Democratization 12.

Scholte, Jan. Aart (2004) Civil Society and Democratically Accountable Global Governance. Government and Opposition 39: 211-33.

Smith, Steve (2000) “US Democracy Promotion: Critical Questions”. In, American Democracy Promotion, edited by Michael Cox, John Ikenberry and Takashi Inoguchi, pp.63-84. Oxford: Oxford University Press.

Snyder, Jack (2000) From Voting to Violence. Democratization and Nationalist Conflict. New York: and London: W. W. Norton.

Svensson, Jakob (1999) Aid, Growth and Democracy. Economics and Politics 11:275-97.

Truman, David (1951) The Governmental Process. New York: Alfred Knopf.

White, Brian (2005) “Diplomacy”. In The Globalization of World Politics, edited by John Baylis and Steve Smith, third edition, pp. 387-403. Oxford: Oxford University Press.

Wolin, Sheldon (1961) Politics and Vision. Continuity and Innovation in Western Political Thought. London: George Allen and Unwin. 
World Bank (2003) World Development Report 2004. Washington, DC: World Bank.

Youngs, Richard (2003) European Approaches to Democracy Assistance: Learning the Right Lessons?

Third World Quarterly 24: 127-38.

Youngs, Richard (2004a) Europe’s Uncertain Pursuit of Middle East Reform. Paper No. 45 (June ).

Washington: CEIP.

Youngs, Richard (2004b) 'Normative Dynamics and Strategic Interests in the EU's External Identity. Journal of Common Market Studies 42: 415-34. 